\title{
Informatics and Communication Technologies (ICT) and In-service Teachers' Training
}

\author{
Giavrimis Panagiotis (Corresponding author) \\ Lecturer, Department of Sociology, University of the Aegean \\ Pamfilis 17, 81100, Mytilene, Greece \\ E-mail: giavrimis@soc.aegean.gr \\ Papastamatis Adamantios \\ Associate Professor, Department of Educational and Social Policy, University of Macedonia \\ Egnatias St. 156, 54006, Thessaloniki, Greece \\ E-mail: papastam@uom.gr \\ Valkanos Efthymios \\ Assistant Professor, Department of Educational and Social Policy, University of Macedonia \\ Egnatias St. 156, 54006, Thessaloniki, Greece \\ E-mail: evalkan@uom.gr \\ Anastasiou Adamos \\ MBA, M.Ed., Ph.D Candidate, University of Macedonia \\ Egnatias St. 156, 54006, Thessaloniki, Greece \\ E-mail: adamosana@gmail.gr
}

Received: February 26, $2011 \quad$ Accepted: March 11, $2011 \quad$ doi:10.5539/res.v3n1p2

\begin{abstract}
This paper is part of a research project which aims to identify the teachers' educational needs and the implementation of Informatics and Communication Technologies (ICT) and its impact on teaching, learning and cognitive processes as well as the students' behavioural adaptation. In the main research, 118 primary school teachers from the island of Lesvos in Greece participated, 36 of them (30.5\%) were male and $82(69.5 \%)$ were female teachers. The questionnaire used in this research consists of seven issue units. Teachers who took part in the research were not totally satisfied with the training that they had already received but on the other hand, they were positive in the idea of continuous training, whereas there are differentiations among demographic units concerning the characteristics of training.
\end{abstract}

Keywords: Informatics and communication technologies in education, Primary education, Training

\section{Introduction}

Contemporary structural theories about language and on-going learning raise questions about the traditional behavioural theories concerning the idea of learning and its theoretical approaches (Kelly, 2006; Matsagouras, 1998, 2007). However, any changes in the educational field seem to pass through the change of teachers' perceptions (James \& Pedder, 2006). The teachers' training and their active participation in the procedures of introducing innovations combined with the encouragement for rethinking in their teaching reality seem to constitute important tools for the change of their perception (Eatona \& Carboneb, 2008; McIntyre \& Byrd, 1998). 
As widely accepted, teachers are in need of continuous training to increase their knowledge and understanding to be able to deal with the new demands (Borko, 2004; Papastamatis \& Kantartzi, 2008). Their initial education and training is not adequate for them to confront successfully the changing social and technological changes and also the changes in knowledge, analytical programmes and in teaching-pedagogic approaches (Duncombe \& Armour, 2004; Griva, Papastamatis, Valkanos, \& Tsakiridou, 2009; Hargreaves, 1998). Today teachers' training and lifelong learning are considered as some of the most important parameters for school effectiveness as well as for the renewing and reforming of the teaching systems (Davis-Kahl \& Payne, 2003). Both the scientific community and the teaching staff strongly believe that training should contribute to the teachers' updating and to the consolidation of their professional efficiency and autonomy by reforming their initial training (Bottery \& Wright, 2000; European Commission, 2003).

Teachers complete and renew their knowledge, understanding and experiences based on their pre-existing acquired knowledge via lifelong learning (Lieberman, 1994). As Mavrogiorgos (1983: 38) claims, "training constitutes the sum of the norms and the activities that are adopted and implemented mostly aiming at the improvement and further development of their academic or practical and their personal or professional knowledge, skills, abilities and interests throughout their career".

\section{ICT teachers' training in Greece}

In Greece, training institutions first appeared with the Legislation decree of 16/3/1881 which abolished the mutual teaching methods and introduced mixed classes teaching methods and at the same time the issue of teachers' training on the latter method becomes urgent (Andreou, 1982: 34). In 1977 the School of In-service Training for Middle Level Teacher Education (S.E.L.M.E.) was founded. In 1979 the institution of the Schools of Training for Primary Level Teacher Education (S.E.L.D.E.) was established and in 1992 the Peripheral In-service Training Centers (PEKs) started their operation (Kynigos \& Xenou, 2000), all of which still operate, unlike the two former Schools of Training. During the last decade, scientific organisations of the Ministry National Education and Religious Affairs such as the Pedagogic Institute, the Organisation of Teacher Training (O.EP.EK) and the various universities have been in charge of the teachers' training under the auspices of the European Support Programmes. The cognitive subjects (knowledge) that are mostly offered in the training procedures concern issues related to the sciences of education and tuition, the school units' administration and management, the teachers' professional development and even subjects that relate to ICT and their implementation in the teaching situation.

Currently, the application of ICT in primary schools constitutes a contemporary necessity, since it is essential for all pupils to be able to cope with the socio-economical frame of our times and acquire skills that are related to ICT (Emvalotis \& Tzimogiannis, 2002; Kynigos \& Xenou, 2000). The teaching and the use of ICT in schools require technologically literate teachers. Therefore, ICT teachers' training is of crucial importance.

As far as Greece is concerned, most of the teachers who work in the educational system of this country are not trained in the use of ICT, since these technologies were incorporated to the official system only at the beginning of the 90s. On the other hand, ICT constitutes a field which changes or evolves at a most rapid rate.

So far, there have been some efforts aiming at teachers' training for use of ICT in Greece. The first one was organized by the Peripheral Training Centers (PEKs) which, as it was afore-mentioned, were established in 1992. Periodic optional seminars took place in these centers aiming at informing teachers about the advances in particular scientific, pedagogic and social fields which were closely and straightforwardly related to their teaching duties. Additionally, they aimed at helping teachers to get accustomed to the use of ICT and multimedia in school units.

As part of the 'Odyssey' action, training of a substantial number of teachers took place, who would then be in charge of the in-service training for the rest of the teachers, adapted to the needs of each school.

Furthermore, according to the Action "Teachers' Training in the Use and the Exploitation of ICT in Educational Teaching Process" of the Action "Teachers' Training in ICT" of the Operational Programme EPEAEK II primary and secondary school teachers' programmes concerning the acquisition of knowledge and skills for the pedagogic exploitation of ICT in the teaching of their cognitive field were materialized.

In this study, we are presenting findings of a wider research that explores the ICT applications to (Greek) primary schools and their impact on teaching, learning and cognitive processes as well as on pupils' behavioural adjustment, according to primary school teachers.

The selection of teachers for this study is based on the premise that: a) they constitute one of the most important links between society and the future generations, b) they have daily contact for many hours per week and a 
clearer perception not only of the educational system but also of pupils and the teaching tools that are used, c) previous studies seem to suggest one of the parameters which acts in an inhibitory way for the successful introduction of ICT in education (as well as for the implementation of innovative actions in general) are the teachers. This occurs because they teach by focusing on the experience that they previously acquired as students (Somekh, 1998). On the other hand, they cannot easily be adjusted to new and unknown situations, but they prefer teaching methods that are familiar to them (Mumtaz, 2000).

The aim of the present study is to look into teachers' opinions about both their training and educational needs concerning ICT. The previously provided training programs did not appear to achieve the expected results (Pavlou \& Vryonides, 2009). The investigation of teachers' needs helps in the better and more effective planning and application of such programs. Moreover, even if the teachers' needs have already been investigated sufficiently, this particular work attempts to modernise them. For these reasons it is hoped that the findings of this study will have some implications for classroom practices, teachers' training and also for the Ministry specific policy.

\section{Method}

\subsection{Participants}

The sample of this specific research consists of 118 teachers of primary schools who worked in the prefecture of Lesvos (Note 1). The total number of primary schools teachers in Lesvos is $720.36(30.5 \%)$ of participants were male while $82(69.5 \%)$ were female teachers. Additionally, $25(21.2 \%)$ of them were under 30 years of age, 40 (33.9\%) were from 30 to 40 years of age, $45(38.1 \%)$ were from 41 to 50 years of age and $8(6.8 \%)$ were from 51 to 60 years age. 94 teachers $(80.34 \%)$ did not hold a degree of further training at that time, whereas only 24 teachers $(19.66 \%)$ were further trained in the past (Table 1$)$. When teachers were asked: 'Have you attended further training programmes in ICT?', $37.61 \%$ answered 'yes' and $62.39 \%$ said 'no'.

[Table 1 about here]

\subsection{The Questionnaire}

For this particular research an questionnaire was designed. Its structure was based on: 1) respective researches and findings through literature review (Drenoyianni, 2004; EURYDICE, 2004, 2005; Fokiali, Koroytsidou, \& Lefas, 2005; Kokkinopoulos, 2006; Machin, McNally \& Silva, 2007; Papanaoum, 2003; Tzimopoulos, 2003; Vitsilaki-Soroniati, 2002); 2) the Primary School Curriculum for the ICT subject (YPEPTH, 2002, 2003); and 3) Ministry of Education, Lifelong Learning and Religious Affairs guidelines on the particular course. The Teachers' Questionnaire concerning ICT is divided into seven thematic sections and also some close questions are included. The first thematic unit refers to the use and the usage of ICT in the educational system (teachers, pupils and school units). The second one refers to the teachers' role in contemporary schools, while the third one includes questions that refer to the acquisition of basic skills related to the pupils' use of computers concerning ICT. The forth thematic unit refers to the factors that make the implementation of ICT in primary schools difficult. The fifth one includes questions that are related to the teachers' knowledge concerning the educational legislation, guidances and newsletters marking the educational reality and the introduction of ICT at schools. In the sixth thematic unit, there are questions related to teachers' training issues concerning ICT. Finally, in the seventh thematic unit questions of sociological interest concerning schools' status in the social context are included. At the beginning of the questionnaire, there are demographic elements that refer to the teachers' age, sex, specialty, the acquisition of a further training diploma or certification, their service status and the length of service. The reliability coefficient of the questionnaire for the split-half test was found .89 and the internal consistency reliability coefficient was found .92 .

\subsection{The Collection of research data}

Initially, there was a contact with the Union of teachers in Lesvos (Greece) with regard to the objectives and the importance of this research for the teachers, and it was mentioned that the findings of that research might become a springboard for planning, organising and implementing training programmes for them. Moreover, the researchers contacted the Pedagogic Institute (PI) and informed them about the exact period of time that the research would be carried out, as well as its aim and its importance. Afterwards, the sample selection was made from the lists of the association with the method of random sampling.

The researchers themselves delivered in person the questionnaire, so that it would be possible for the participants to have direct, timely and valid clarifications, in case that they might have any problems. In addition, there was a cover-letter that informed every participant about the aim of the research and assured him/her that the content of his/her answers would be confidential. 


\section{Results}

According to the teachers' opinions referring to their training and concerning issues of Informatics education, a small percentage of teachers $(5.56 \%)$ believed that the training they acquired was successful or believed that it was the appropriate one (4.48\%) (see Table 2). Most of the teachers believed from 'A little' to 'Enough' that the training they acquired during their professional career for the introduction Computer Science at schools was successful or appropriate. On the contrary, these was a significant percentage of about $12 \%$ who regarded their acquired training neither successful nor appropriate. The differences in the teachers' opinions were found to be meaningful but not statistically significant.

[Table 2 about here]

By using multiple response questions, teachers expressed the following factors as the cause for making the implementation of ICT at schools difficult. Specifically, they referred to the insufficient teachers' training (67.24\%), the absence of satisfactory material equipment (63.79\%) and the non-flexible curriculum (69.48\%). These factors were followed by insufficient teachers' briefing, the insufficient financing and the implementation of other programmes off the Daily Programme. The last factor that the teachers regarded of less importance was the lack of interest on their part $(19.83 \%)$. The results revealed that teachers attach great importance to their training, the material substructure of the whole educational system and the pressure they feel because of the non-flexible curriculum. The majority of the teachers seem to be interested in the introduction of ICT in education (Figure 1).

[Figure 1 about here]

Figure 2 shows that an important percentage of teachers fluctuating between $29.57 \%$ ('A lot') and $42.61 \%$ ('Enough') felt that there was an insufficient teachers' briefing/training concerning the potentials presented by ICT in teaching. A small percentage of teachers $(4.35 \%)$ however felt that briefing/training concerning the potentials supplied by ICT in teaching were sufficient. Furthermore, $23.48 \%$ of the teachers agreed only to this opinion. The differences in the teachers' opinions were examined with the use of the $\chi^{2}$ criterion and it was found that the differentiation concerning these percentages was statistically significant.

[Figure 2 about here]

Analysis suggests teachers were of the opinion that their training should be continual and systematic (in certain periods of the teachers' career) and be performed in schools adapted to the needs of each school unit separately (in-service). They also believed that training should be performed outside school working hours when teachers are released from teaching duties and it should be of long duration (such as a six-month period). A small percentage of teachers $(25 \%)$ gave less importance to such opinions and a similar percentage $(25 \%)$ of the teachers believed that training should be of a long duration (such as a six-month period) and be carried out with the teachers released from their teaching duties. These opinions clearly show that they consider their training to be of a long duration, systematic and supported by service standards and adapted to the needs of the school environment.

\section{[Table 3 about here]}

Mann-Whitney U Test was conducted to examine the influence of the 'Sex' (Male-Female) on the teachers' responses. The findings indicate a statistical significant differentiation between the two sexes concerning the question "Is there sufficient teachers' briefing/training concerning the potentials supplied by ICT in teaching?" (Mann-Whitney=1058, $\mathrm{Z}=--2,34, p<.05$ ) (Table 4). With regard to the answers concerning the remaining questions these were hardly any differences between male and female teachers. Consequently, women seem to believe more firmly than men in the insufficient teachers' briefing/training in connection to the possibilities that ICT may provide the teaching process with (Table 4).

[Table 4 about here]

Kruskal-Wallis Test was conducted to examine whether there is a statistical difference in the responses according to their age levels. Test produced a significant statistical difference only for the question concerning the teacher's acquittal from their teaching duties when they are trained $\left[\chi^{2}(3)=30463, p<.05\right]$ (Table 6). As far as the rest of the questions are concerned, there is no differentiation in the responses among the people's age levels. The results described above suggested that: a) the more the age is increased up to 50 years, the more firm the afore-mentioned opinion is and b) the people at the age of 51 and over seem to differentiate from this opinion.

[Table 5 about here] 
Finally Mann-Whitney Test was conducted to examine the influence of the 'Further Training' concerning the responses about the training of those people who participated in our sample. As far as the findings of the analyses are concerned, there seems to be no actual statistical differentiation in the opinions about the training between those people that hold only a BA and those who have acquired (apart from their BA title) any kind of further training. As a result, it can be seen quite easily that further training does not differentiate the teachers' opinions concerning their training in ICT (Table 6).

[Table 6 about here]

\section{Discussion}

Our era requires from teachers the acquisition of knowledge and skills through processes of professional development that are offered via the continual training procedure starting from the beginning of their career until their retirement. The initial training is regarded insufficient in offering to teachers all the necessary knowledge and skills that are needed throughout their professional life (Duncombe \& Armour, 2004; Papanaoum, 2003). The introduction of ICT at schools and their rapid evolution makes the implementation of training programmes imperative more than ever. The findings of this research show that the first factor which makes the implementation of ICT at school difficult is the insufficient teachers' training concerning issues of Computer Education. A small percentage of teachers believe that the training they acquired was very successful or that it was appropriate. The majority of teachers believe from 'A little' to 'Enough' that the training they acquired during their professional route concerning ICT (mostly about learning basic skills) was successful or appropriate. We should point out that the one tenth of the teachers is absolutely negative to the findings of this research concerning ICT. The above opinions agree with the finding that an important percentage of teachers believe from 'Enough' (42.61\%) to 'A lot' (29.57\%), that there is insufficient teachers' briefing/training concerning the possibilities ICT may provide the teaching process with. All these elements seem to be influenced by the teachers' age and their sex and as a result, also by their experience inside the educational system. According to some either international or Greek research papers, teachers stand positively towards their training (Batsouta \& Papagiannidou, 2006; Bikos, 1995; Emvalotis \& Tzimogiannis, 2002; Karagiorgi \& Symeou, 2007; Papanaoum, 2003; Tzimogiannis \& Komis, 2004) but they sometimes point out that it may not approach their personal needs or even be insufficient (Hargreaves, 1998; Hustler, McNamara, Jarvis, Londra \& Campbell, 2003; Smith, 2004). Furthermore, the teachers point out that their training should be continual and systematic (taking place in certain periods of their career) and be carried out in schools adjusted to the needs of every school unit separately (in-service). Moreover, they believe that their training should take place off working school hours, with teachers' acquittal from their teaching duties and be mostly of long duration (such as a six-month period). These findings are in agreement with other some Greek and international researches (Edmonds, 2007; Fokiali et al., 2005; Goliaris, 1998. Karagiorgi \& Symeou, 2007, 2008; Papanaoum, 2005). The training models have changed approaching formats different from the traditional ones which were based on educational processes that took place outside the school environment in institutions and frameworks that provided education. According to the new training forms, the in-service training, the mentor's coaching and the practical work in school classes are included (Graham \& Thornley, 2000; Martinez \& Coombs, 2001).

\section{Conclusion}

In conclusion, the teachers considered that the improper application of ICT in the educational practice derived from their insufficient teachers' training in ICT. They also regarded as an imperative necessity the fact that their training should be continuous and systematic, off working school hours and with teachers acquittal from their teaching duties and of long duration and suitable for the school unit in which teachers would be integrated. The effective cover up of teachers' needs reinforces the more effective integration of ICT in their teaching process as well as in their use in general (Emvalotis \& Tzimogiannis, 2002; Papanaoum, 2003; Pavlou \& Vryonides, 2009; Tzimogiannis \& Earl, 2004).

It should be pointed out that technology on its own, irrespective of its quality and range, presents limited potentials for the learning support. In other words, if technology is considered as a simple attachment of the learning environment that is used for the sake of the plain technological advancements of the school environment, then the possibility of activating the learning mechanism is becoming minimized. It is important, therefore, that teachers' training should be focused on new pedagogical approaches concerning teaching, learning and classroom management.

Training should necessarily lead towards the development of teachers' skills and qualifications which can support the implementation of innovative programmes and teaching techniques aiming at the cultivation of 
cognitive structures that form the critical thought and the formation of free and contemporary citizens from all kinds of perspectives.

So far, education aimed basically at the citizens' preparation for a society almost identical to the each time 'modern' one. Nowadays, for the first time we are training a generation that is about to live in an absolutely different environment. We are forced to handle the demand of preparing citizens for the unknown. For this reason, it is regarded essential for an effective teacher to aim steadily at that kind of teaching that should be oriented towards the creation of citizens who have acquired critical thought. These citizens will be capable of confronting successfully not only all the rapid changes that affect global economy and society but also the huge technological steps that occurred during the last fifty years and reveal our response to the expectations of contemporary societies.

Finally, the Ministry of Education should adapt teachers' training to the needs of teachers and the general educational system in the contemporary developing and post-modern environment. In addition, it is of crucial importance to take into consideration all the elements that concern the lack of sufficient material and technical substructure, the inflexible Curriculum of Studies and the insufficient financing as well.

\section{References}

Andreou, A. (1982). Review of institution of training of teachers in our country. Sinhroni Ekpedefsi, 9, 34-41 [in Modern Greek].

Batsouta, M. \& Papagiannidou, H. (2006). Research in training needs of preschool teachers. Epitheorisi Ekpedeftikon Thematon, 11, 143-157 [in Modern Greek].

Bikos, K. (1995). Teachers and computers: Attitudes of Greek teachers towards the use of computers in the General Education. Thessaloniki, Greece: Kyriakidis [in Modern Greek].

Borko, H. (2004). Professional development and teacher learning: mapping the terrain. Educational Researcher, 33(8), 3-15. doi:10.3102/0013189X033008003, http://dx.doi.org/10.3102/0013189X033008003

Bottery, M., \& Wright, N. (2000). Teachers and the state: Towards a directed profession. London: Routledge.

Davis-Kahl, S., \& Payne, L. (2003). Teaching, learning and research: linking high school teachers to information literacy. Reference Service Review, 31(4), 313-319. doi:10.1108/00907320310505609, http://dx.doi.org/10.1108/00907320310505609

Drenoyianni, H. (2004). Designing and implementing a project-based ICT course in a teacher education setting: rewards and pitfalls. Education and Information Technologies, 9(4), $387-404$. doi:10.1023/B:EAIT.0000045295.26962.8a, http://dx.doi.org/10.1023/B:EAIT.0000045295.26962.8a

Duncombe, R., \& Armour, K. (2004). Collaborative professional learning: From theory to practice. Journal of In-Service Education, 30(1), 141-166. doi:10.1080/13674580400200230, http://dx.doi.org/10.1080/13674580400200230

Eatona, T.P., \& Carboneb, R.E. (2008). Asking those who know: a collaborative approach to continuing professional development. Teacher Development, 12(3), 261-270. doi:10.1080/13664530802259388, http://dx.doi.org/10.1080/13664530802259388

Edmonds, C. (2007). Continuous quality improvement: integrating best practice into teacher education. International Journal of Educational Management, 21(3), 232-237. doi:10.1108/09513540710738674, http://dx.doi.org/10.1108/09513540710738674

Emvalotis, A., \& Tzimogiannis, A. (2002). Attitudes of teachers of region of Ioannina towards the New $\begin{array}{llll}\text { Technologies in the Lyceum. [Online] Available: } & \end{array}$ http://www.etpe.gr/extras/download.php?type=proceed\&id=428 [in Modern Greek].

European Commission. (July 2003). Implementation of “Education \& Training 2010" Work Programme: Stading Group of Indicators and Benchmarks. [Online] Available: http://www.europa.eu.int/comm/education/policies/2010/doc/ idicators-and benchmarks_en.pdf.

Eurydice. (2004). Key Data on Information and Communication Technology in Schools in Europe. Brussels: Eurydice European Unit.

Eyrydice. (2005). How boys and girls in Europe get familiarised with ICT. [Online] Available: http://eacea.ec.europa.eu/ressources/eurydice/pdf/ 0_integral/069EL. pdf [in Modern Greek].

Fokiali, P., Kouroutsidou, M. \& Lefas, E. (2005). Demand for training: The components of professional 
development of teachers. In G. Bagakis (Ed.), Training and professional development of teacher (pp. 131-138). Athens, Greece: Metaihmio [in Modern Greek].

Goliaris, H. (1998). The training needs of elementary teachers. Sinhroni Ekpedefsi, 101, 83-88 [in Modern Greek].

Graham, S., \& Thornley, C. (2000). Connecting classrooms in pre-service education: conversations for learning. Asia-Pacific Journal of Teacher Education, 28(3), 235-45. doi:10.1080/713650697, http://dx.doi.org/10.1080/713650697

Griva, E., Papastamatis, A., Valkanos, E., \& Tsakiridou, E. (2009 November). A study of the in-service needs of the instructors employed in Greek Second Chance Schools. In Personal author, compiler, or editor name(s); click on any author to run a new search on that name. In A. Papastamatis, E. Valkanos, G Zarifis, \& E. Panitsidou (Eds), Educating the adult educator: Quality provision and assessment in Europe (pp. 623-633). ESREA|ReNAdET.

Hargreaves, D. (1998). Creative professionalism: The role of teachers in the knowledge society. London, UK: DEMOS.

Hustler, D., McNamara, O., Jarvis, J., Londra, M. \& Campbell, A. (2003). Teachers' perceptions of continuing professional development. Nottingham, UK: DfES. [Online] Available: http://www.dfes.gov.uk/research/data/ uploadfiles/RR429.pdf.

James, M., \& D. Pedder. (2006). Beyond method: Assessment and learning practices and values. Curriculum Journal, 17(2), 109-38. doi:10.1080/09585170600792712, http://dx.doi.org/10.1080/09585170600792712

Karagiorgi, Y. \& Symeou, L. (2007). Teachers' in-service training needs in Cyprus. European Journal of Teacher Education, 30(2), 175-194. doi:10.1080/02619760701275487, http://dx.doi.org/10.1080/02619760701275487

Karagiorgi, Y. \& Symeou, L. (2008). Through the eyes of the teachers: revisiting in-service training practices in Cyprus. Teacher Development, 12(3), 247-259. doi: 10.1080/13664530802259305, http://dx.doi.org/10.1080/13664530802259305

Kelly, P. (2006). What is teacher learning? A socio-cultural perspective. Oxford Review of Education, 32(3), 505-519. doi:10.1080/03054980600884227, http://dx.doi.org/10.1080/03054980600884227

Kokkinopoulos, A. (2006). Expression of experiences after teachers' participation and attendance in training programmes which were held in certified K.S.E. The case K.S.E. in A' Athens. Patra, Greece: Hellenic Open University (master thesis).

Kynigos, H., \& Xenou, N. (2000). New practices with new tools in the class: Training of teachers for the creation of communities of exploitation of new technology in the school. [Online] Available: http://www.etpe.gr/extras/download. php?type=proceed\&id=712 [in Modern Greek].

Lieberman, A. (1994). Teacher development: commitment and challenge. In P.P. Grimett \& J. Neufeld (Eds), Teacher development and the struggle of authenticity: Professional development and restructuring in the context of change. New York Teachers: College Press.

Machin, S., McNally, S., \& Silva, O. (2007). New Technologies in Schools: Is There a Payoff? The Economic Journal, 117(522), 1145-1167. doi:10.1111/j.1468-0297.2007.02070.x, http://dx.doi.org/10.1111/j.1468-0297.2007.02070.x

Martinez, K., \& Coombs, G. (2001). Unsung heroes: exploring the roles of school-based professional experience coordinators in Australian pre-service teacher education. Asia-Pacific Journal of Teacher Education, 29(3), 275-288. doi:10.1080/13598660120091874, http://dx.doi.org/10.1080/13598660120091874

Matsagouras, E. (1998). Teaching strategies. Athenes: Gutenberg [in Modern Greek].

Matsagouras, E. (2007). Modern pedagogic and educational subjects. Athens, Greece: Gutenberg [in Modern Greek].

Mavrogiorgos, G. (1983). Forms of training: Conceptual declarations. The political-social framework. Conditions. Synchroni Ekpaidefsi, 10, 37-52 [in Modern Greek].

McIntyre, D.J. \& Byrd, D.M. (Eds) (1998). Strategies for careerlong teacher education. Thousand Oaks, CA: Teacher Education Yearbook VI, Corwin Press.

Mumtaz, S. (2000). Factors affecting teachers use of information and communications technology: a review of 
the literature. Journal of Information Technology for Teacher Education, 9 (3), 319-341. doi:10.1.1.118.6820, http://dx.doi.org/10.1.1.118.6820

Papanaoum, Z. (2003). The profession of Teacher: Theoretical and empirical approach. Athens, Greece: Tipothito-G. Dardianos [in Modern Greek].

Papanaoum, Z. (2005). The role of training of teachers in their professional growth: why, when, how? In G Bagakis (Ed.) Training and professional development of teacher. Athens, Greece: Metaixmio [in Modern Greek].

Papastamatis, A., \& Kantartzi, E. (2008). Improving staff development through evaluation. In N. Terzis (Ed), European unification and educational challenges in the Balkans, No 8 (pp. 327 - 336). Thessaloniki, Greece: Kyriakidis Brothers [in Modern Greek].

Pavlou, V. \& Vryonides, M. (2009). Understanding factors that influence teachers' acceptance of technology and actual computer use for teaching: the case of Greece. Mediterranean Journal of Educational Studies, 14, 5-25.Smith, A. (2004). Making mathematics count. London: The Stationery Office.

Somekh, B. (1998). Supporting Information and Communication Technology Innovations in Higher Education. Journal of Information Technology for Teacher Education, 7(1), 11-33. doi:10.1.1.15.1075, http://dx.doi.org/10.1.1.15.1075

Tzimogiannis, A., \& Komis, V. (2004). Attitudes and perceptions of teachers of secondary education with regard to the application of ICT in their teaching. [Online] Available: http://www.etpe.gr/extras/download.php? type $=$ proceed $\&$ id $=15$ [in Modern Greek].

Tzimopoulos, N. (2003). The teachers' training in the new technologies of information and communications. The case of the introductory training programmes in the municipality of Cyclades. master thesis, Patra, Greece, Hellenic Open University.

Vitsilaki-Soroniati, Ch. (2002). Life long training of teachers: A case study of the program of development of teachers of Primary Education. Epistimes Agogis, 2, 43-44.

\section{Note}

Note 1. Lesvos is one of the three prefectures of the Region of Northern Aegean (Greece), which includes also Chios and Samos. The Prefecture of Lesvos consists of 3 islands: Lesvos, Lemnos and Agios Eustratios, of which Lesvos is considered the center of the Region of Northern Aegean. The total extent of Lesvos is 2,154 $\mathrm{km}^{2}$, the total length of coasts is $696 \mathrm{~km}$, and the total population is 105,194 people. The capital city of the island is Mytilene, where the central offices of the Regional Authority of Northern Aegean and the Head Offices of the University of the Aegean are located.

Table 1. Absolute and relative frequencies of sex, age levels and the teachers' further training acquisition

\begin{tabular}{llll}
\hline Variable & Level & Absohute frequency & Relative frequency \\
\hline \multirow{3}{*}{ Sex } & Male & 36 & 30.5 \\
& Female & 82 & 69.5 \\
& Total & 118 & 100.0 \\
\hline \multirow{4}{*}{ Age level } & Below 30 & 25 & 21.2 \\
& $30-40$ & 40 & 33.9 \\
& $41-50$ & 45 & 38.1 \\
& $51-60$ & 8 & 68 \\
Further training & Total & 118 & 100.0 \\
& Yos & 94 & 80.34 \\
& Total & 118 & 19.66 \\
\hline
\end{tabular}


Table 2. Absolute and relative frequencies and $\chi^{2}$ criterion

\begin{tabular}{|c|c|c|c|c|c|c|}
\hline QUESTIONS & $\begin{array}{l}\text { Not at all } \\
\text { N }(\%)\end{array}$ & $\begin{array}{l}\text { A little } \\
\mathrm{N}(\%)\end{array}$ & $\begin{array}{l}\text { Enough } \\
\mathrm{N}(\%)\end{array}$ & $\begin{array}{l}\text { A 1ot } \\
N(\%)\end{array}$ & $\begin{array}{l}\text { Total } \\
\text { N (\%) }\end{array}$ & $\chi^{2}(3)$ \\
\hline $\begin{array}{l}\text { Do you believe that the } \\
\text { training you acquired was } \\
\text { successful? }\end{array}$ & $\begin{array}{l}9 \\
(12.5)\end{array}$ & $\begin{array}{l}30 \\
(41.67)\end{array}$ & $\begin{array}{l}29 \\
(40.28)\end{array}$ & $\begin{array}{l}4 \\
(5.56)\end{array}$ & $\begin{array}{l}72 \\
(100)\end{array}$ & $30.12^{*}$ \\
\hline $\begin{array}{l}\text { Do you believe that the } \\
\text { training you acquired was the } \\
\text { appropriate one? }\end{array}$ & $\begin{array}{l}8 \\
(11.94)\end{array}$ & $\begin{array}{l}31 \\
(46.27)\end{array}$ & $\begin{array}{l}25 \\
(37.31)\end{array}$ & $3(4.48)$ & $\begin{array}{l}72 \\
(100)\end{array}$ & $32.05^{*}$ \\
\hline
\end{tabular}

Note: $*=\mathrm{p}<.00$

Table 3. Median, minimum and maximum and quartiles

\begin{tabular}{|c|c|c|c|c|c|c|}
\hline \multirow{2}{*}{ The training in ICT should be } & \multirow{2}{*}{ Median } & \multirow{2}{*}{ Min } & \multirow{2}{*}{ Max } & \multicolumn{3}{|c|}{ Quartiles } \\
\hline & & & & 25 & 50 & 75 \\
\hline Mostly of long duration (such as a six-month period). & 3 & 1 & 4 & 2 & 3 & 4 \\
\hline Performed mostly off working school hours. & 3 & 1 & 4 & 2 & 3 & 3 \\
\hline $\begin{array}{l}\text { Performed with teachers' acquittal form their teaching } \\
\text { duties. }\end{array}$ & 3 & 1 & 4 & 2 & 3 & 4 \\
\hline $\begin{array}{l}\text { Continual and systematic (in certain periods of the } \\
\text { teachers' career). }\end{array}$ & 4 & 1 & 4 & 3 & 4 & 4 \\
\hline $\begin{array}{l}\text { Performed in schools adjusted to the needs of each school } \\
\text { unit separately (in-service). }\end{array}$ & 4 & 1 & 4 & 3 & 4 & 4 \\
\hline
\end{tabular}

Table 4. Mean Rank and Mann-Whitney U Test concerning the variable 'Sex'

\begin{tabular}{|c|c|c|c|c|c|}
\hline The training should be: & $\begin{array}{l}\text { Mann-Whitney } \\
\text { U }\end{array}$ & $z$ & $\begin{array}{l}\text { Asymp. } \\
\text { Sig. } \\
\text { (2-tailed) }\end{array}$ & Sex & $\begin{array}{l}\text { Mean } \\
\text { Rank }\end{array}$ \\
\hline \multirow{2}{*}{$\begin{array}{l}\text { Continual and systematic (in certain periods } \\
\text { of the teachers' career). }\end{array}$} & \multirow{2}{*}{1308.50} & \multirow{2}{*}{-.81} & \multirow{2}{*}{.42} & Male & 54.85 \\
\hline & & & & Female & 59.44 \\
\hline \multirow{2}{*}{$\begin{array}{l}\text { Performed in schools adjusted to the needs } \\
\text { of each school unit separately (in-service). }\end{array}$} & \multirow{2}{*}{1372.50} & \multirow{2}{*}{-.19} & \multirow{2}{*}{.85} & Male & 57.21 \\
\hline & & & & Female & 58.34 \\
\hline \multirow{2}{*}{$\begin{array}{l}\text { Mostly of long duration (such as a } \\
\text { six-month period). }\end{array}$} & \multirow{2}{*}{1245.00} & \multirow{2}{*}{-.88} & \multirow{2}{*}{.38} & Male & 53.57 \\
\hline & & & & Female & 59.24 \\
\hline \multirow{2}{*}{ Performed mostly off working school hours. } & \multirow{2}{*}{1257.5} & \multirow{2}{*}{-.69} & \multirow{2}{*}{49} & Male & 53.93 \\
\hline & & & & Female & 58.38 \\
\hline \multirow{2}{*}{$\begin{array}{l}\text { Performed with teachers' acquittal form } \\
\text { their teaching duties. }\end{array}$} & \multirow{2}{*}{1421} & \multirow{2}{*}{-.23} & \multirow{2}{*}{.82} & Male & 57.97 \\
\hline & & & & Female & 59.46 \\
\hline \multirow{2}{*}{$\begin{array}{l}\text { There is insufficient teachers' briefing / } \\
\text { training concerning the potentials supplied } \\
\text { by ICT in teaching. }\end{array}$} & \multirow{2}{*}{1058} & \multirow{2}{*}{-2.34} & \multirow{2}{*}{$.02 *$} & Male & 47.89 \\
\hline & & & & Female & 62.61 \\
\hline
\end{tabular}

Note: 1. Not at all, 2. A little, 3. Enough, 4. A lot 
Table 5. Mean Rank, $\chi 2$ concerning the variable 'Age levels'

\begin{tabular}{|c|c|c|c|c|}
\hline The training should be: & $x^{2}(3)$ & Sig. & Age levels & $\begin{array}{l}\text { Mean } \\
\text { Rank }\end{array}$ \\
\hline \multirow{4}{*}{$\begin{array}{l}\text { Continual and systematic (in certain periods of the } \\
\text { teachers' career). }\end{array}$} & \multirow{4}{*}{1.44} & \multirow{4}{*}{.69} & Bel ow 30 & 62.75 \\
\hline & & & $30-40$ & 54.51 \\
\hline & & & $41-50$ & 59.07 \\
\hline & & & $51-60$ & 55.44 \\
\hline \multirow{4}{*}{$\begin{array}{l}\text { Performed in schools adjusted to the needs of each } \\
\text { school unit separately (in-service). }\end{array}$} & \multirow{4}{*}{1.39} & \multirow{4}{*}{.70} & Bel ow 30 & 52.48 \\
\hline & & & $30-40$ & 57.59 \\
\hline & & & $41-50$ & 60.95 \\
\hline & & & $51-60$ & 61.38 \\
\hline \multirow{4}{*}{ Mostly of long duration (such as a six-month period). } & \multirow{4}{*}{4.27} & \multirow{4}{*}{.23} & Bel ow 30 & 50.94 \\
\hline & & & $30-40$ & 55.80 \\
\hline & & & $41-50$ & 59.37 \\
\hline & & & $51-60$ & 78.21 \\
\hline \multirow{4}{*}{ Performed mostly off working school hours. } & \multirow{4}{*}{1.54} & \multirow{4}{*}{.67} & Bel ow 30 & 59.81 \\
\hline & & & $30-40$ & 58.63 \\
\hline & & & $41-50$ & 52.52 \\
\hline & & & $51-60$ & 64.13 \\
\hline \multirow{4}{*}{$\begin{array}{l}\text { Performed with teachers' acquittal form their } \\
\text { teaching duties. }\end{array}$} & \multirow{4}{*}{14.31} & \multirow{4}{*}{$.00^{*}$} & Below 30 & 45.38 \\
\hline & & & $30-40$ & 52.50 \\
\hline & & & $41-50$ & 73.18 \\
\hline & & & $51-60$ & 56.06 \\
\hline \multirow{4}{*}{$\begin{array}{l}\text { There is insufficient teachers briefing / training } \\
\text { concerning the potentials supplied by ICT in } \\
\text { teaching. }\end{array}$} & \multirow{4}{*}{.19} & \multirow{4}{*}{.97} & Bel ow 30 & 60.38 \\
\hline & & & $30-40$ & 57.68 \\
\hline & & & $41-50$ & 57.30 \\
\hline & & & $51-60$ & 56.31 \\
\hline
\end{tabular}

Note: 1. Not at all, 2. A little, 3. Enough, 4. A lot

Table 6. Mean Rank and Mann-Whitney U Test of the questions concerning the variable 'Further Training'

\begin{tabular}{|c|c|c|c|c|c|}
\hline The training should be: & $\begin{array}{l}\text { Mann-Whitney } \\
\text { U }\end{array}$ & $z$ & Sig. & $\begin{array}{l}\text { Further } \\
\text { Training }\end{array}$ & $\begin{array}{l}\text { Mean } \\
\text { Rank }\end{array}$ \\
\hline \multirow{2}{*}{$\begin{array}{l}\text { Continual and systematic (in certain periods of the } \\
\text { teachers' career). }\end{array}$} & \multirow{2}{*}{995} & \multirow{2}{*}{-.43} & \multirow{2}{*}{.67} & NO & 58.07 \\
\hline & & & & YES & 55.26 \\
\hline \multirow{2}{*}{$\begin{array}{l}\text { Performed in schools adjusted to the needs of each } \\
\text { school unit separately (in-service). }\end{array}$} & \multirow{2}{*}{861} & \multirow{2}{*}{-1.22} & \multirow{2}{*}{.22} & NO & 59.14 \\
\hline & & & & YES & 50.64 \\
\hline \multirow{2}{*}{$\begin{array}{l}\text { Mostly of long duration (such as a six-month } \\
\text { period). }\end{array}$} & \multirow{2}{*}{916.5} & \multirow{2}{*}{-.64} & \multirow{2}{*}{.52} & NO & 56.07 \\
\hline & & & & YES & 60.84 \\
\hline \multirow{2}{*}{ Performed mostly off working school hours. } & \multirow{2}{*}{941} & \multirow{2}{*}{-.37} & \multirow{2}{*}{.71} & NO & 57.04 \\
\hline & & & & YES & 54.27 \\
\hline \multirow{2}{*}{$\begin{array}{l}\text { Performed with teachers' acquittal form their } \\
\text { teaching duties. }\end{array}$} & \multirow{2}{*}{852} & \multirow{2}{*}{-1.57} & \multirow{2}{*}{.12} & NO & 56.16 \\
\hline & & & & YES & 67.96 \\
\hline \multirow{2}{*}{$\begin{array}{l}\text { There is insufficient teachers' briefing / training } \\
\text { concerning the potentials supplied by ICT in } \\
\text { teaching. }\end{array}$} & \multirow[b]{2}{*}{1037} & \multirow[b]{2}{*}{-.07} & \multirow[b]{2}{*}{.94} & NO & 57.60 \\
\hline & & & & YES & 57.09 \\
\hline
\end{tabular}

Note: 1. Not at all, 2. A little, 3. Enough, 4. A lot 


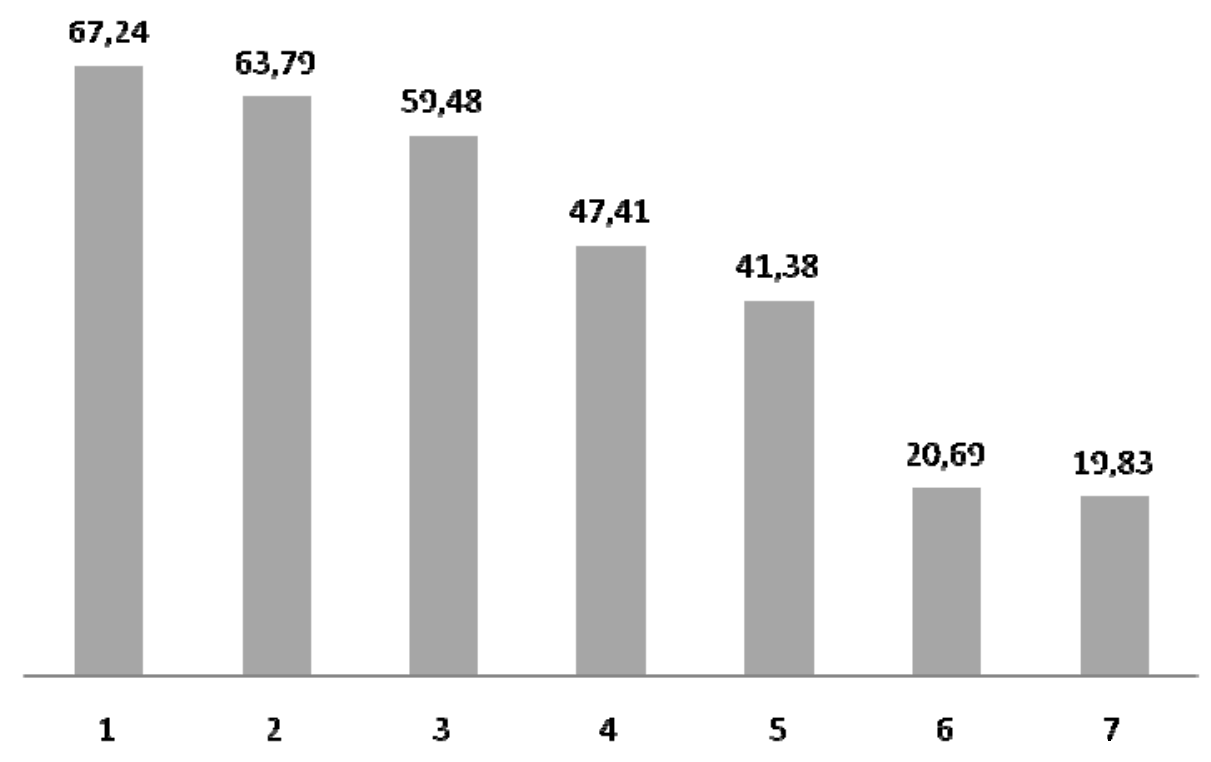

Figure 1. Graphic draft of the percentage analogies of the pupils' positive answers concerning the question about the factors that in their opinion make the implementation of ICT in schools difficult found in the Teachers' Questionnaire for ICT.

Note: 1. The insufficient teachers' training, 2. The absence of satisfactory material equipment, 3. The non-flexible curriculum, 4. The insufficient teachers' briefing, 5. The insufficient financing, 6. The implementation of other programmes off the Daily Programme, 7. The lack of interest on the teachers' part.

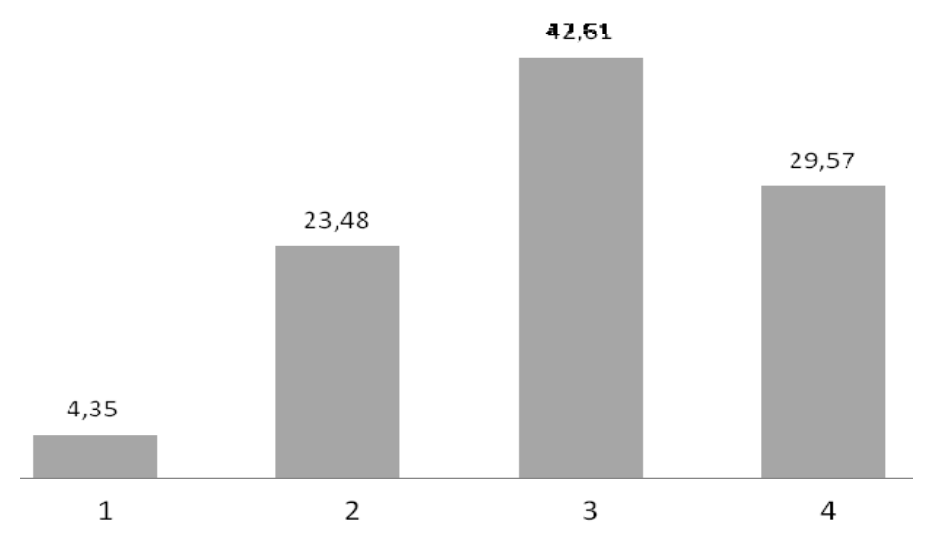

Figure 2. Graphic draft of the percentage analogies of the question 'Is there sufficient briefing/training concerning the potentials supplied by ICT in teaching?' found in the Teachers' Questionnaire for ICT.

Note: 1. Not at all, 2. A little, 3. Enough, 4. A lot 